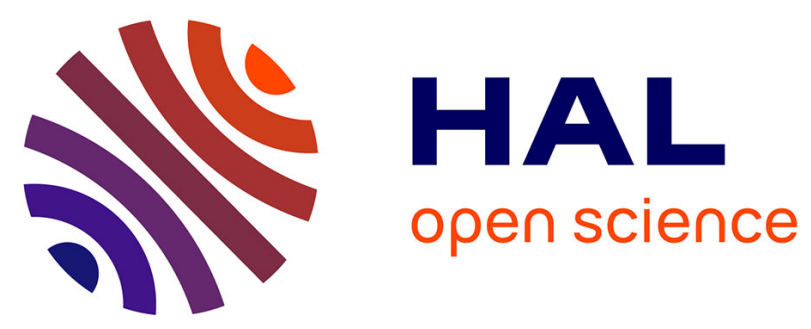

\title{
Electrochemical redox processes involved in carbon-coated KVPO4F for high voltage K-ion batteries revealed by XPS analysis
}

Laure Caracciolo, Lénaïc Madec, Emmanuel Petit, Vincent Gabaudan, Dany

Carlier, Laurence Croguennec, Hervé Martinez

\section{To cite this version:}

Laure Caracciolo, Lénaïc Madec, Emmanuel Petit, Vincent Gabaudan, Dany Carlier, et al.. Electrochemical redox processes involved in carbon-coated KVPO4F for high voltage K-ion batteries revealed by XPS analysis. Journal of The Electrochemical Society, 2020, 167 (13), 130527 (4 p.). 10.1149/19457111/abbb0c . hal-02982857

\section{HAL Id: hal-02982857 \\ https://hal.umontpellier.fr/hal-02982857}

Submitted on 6 Nov 2020

HAL is a multi-disciplinary open access archive for the deposit and dissemination of scientific research documents, whether they are published or not. The documents may come from teaching and research institutions in France or abroad, or from public or private research centers.
L'archive ouverte pluridisciplinaire HAL, est destinée au dépôt et à la diffusion de documents scientifiques de niveau recherche, publiés ou non, émanant des établissements d'enseignement et de recherche français ou étrangers, des laboratoires publics ou privés. 


\title{
Electrochemical redox processes involved in carbon-coated $\mathrm{KVPO}_{4} \mathrm{~F}$ for high voltage $\mathrm{K}$ - ion batteries revealed by XPS analysis
}

\author{
Laure Caracciolo ${ }^{\mathrm{a}}$, Lénaïc Madec ${ }^{\mathrm{a}, \mathrm{d}, *}$, Emmanuel Petit ${ }^{\mathrm{b}, \mathrm{d}}$, Vincent Gabaudan ${ }^{\mathrm{c}, \mathrm{d}}$, Dany

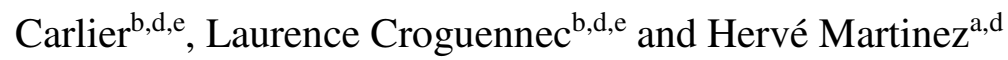

${ }^{\text {a }}$ CNRS/ UNIV Pau \& Pays Adour/ E2S UPPA, Institut des Sciences Analytiques et de Physicochimie pour l’Environnement et les Matériaux, UMR5254, 64000, Pau, France

${ }^{\mathrm{b}}$ CNRS, University Bordeaux, Bordeaux INP, ICMCB UMR5026, F-33600 Pessac, France

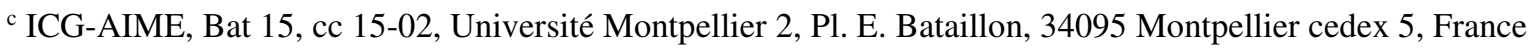

d Réseau sur le Stockage Electrochimique de l'Energie (RS2E), CNRS FR3459, 33 Rue Saint Leu, 80039

Amiens Cedex, France

e ALISTORE-ERI European Research Institute, FR CNRS \#3104, Amiens, F-80039 Cedex 1, France

* Corresponding author : lenaic.madec@univ-pau.fr

\begin{abstract}
K-ion batteries need efficient positive electrode materials with open structural frameworks to accommodate the large ionic radius of $\mathrm{K}^{+}$. In that direction, polyanionic compounds are of great interest. Among them, $\mathrm{KVPO}_{4} \mathrm{~F}$ is the most studied one. Its electrochemical redox processes still remain unclear, especially at high voltage. To tackle this issue, X-ray photoelectron spectroscopy was used to reveal the electrochemical redox processes of $\mathrm{K}_{\mathrm{x}} \mathrm{VPO}_{4} \mathrm{~F}$. First, a carbon coating was performed and allowed increasing the overall electrochemical performance while mitigating electrolyte degradation at high voltage. Then, XPS analysis showed a high reversibility of the redox processes although the $\mathrm{K}^{+}$extraction (and insertion) from $\mathrm{x}=0.5$ to 0
\end{abstract}


was hindered, possibly by structural constraints while electrolyte degradation occurred mostly above $4.5 \mathrm{~V}$.

\section{Introduction}

The development of new electrochemical energy storage systems as alternatives to the Li-ion technology remains a key challenge due to the growth of energy storage demand. Alternative batteries based on abundant and thus low cost raw materials are required. Na-ion and K-ion batteries have attracted increasing interest during the last decade. Thanks to the low potential of the $\mathrm{K}^{+} / \mathrm{K}$ redox couple versus the other alkali metals in non-aqueous solvents, high voltage K-ion batteries (KIBs) could be developed. ${ }^{1}$ Moreover, $\mathrm{K}^{+}$has the lowest Lewis acidity and desolvation energy compared to $\mathrm{Na}^{+}$and $\mathrm{Li}^{+},{ }^{2}$ and thus higher ionic conductivity and faster electrode/electrolyte interface diffusion kinetics that would allow developing high power KIBs.

The high reactivity of $\mathrm{K}$ metal requires considering results obtained in half-cells with caution, especially the interaction between the electrolyte and the electrode surface. Indeed, migration of electrolyte degradation products can occur from the $\mathrm{K}$ metal to the working electrode. ${ }^{3}$ Among negative electrode materials, ${ }^{4}$ graphite is of great interest as it reversibly intercalates $\mathrm{K}^{+}$to form $\mathrm{KC}_{8} \cdot{ }^{5,6,7}$ Promising electrochemical performance is obtained, with a reversible capacity of $\sim 250 \mathrm{mAh} \cdot \mathrm{g}^{-1}$ up to hundreds of cycles and even for high practical loading (> $\left.20 \mathrm{mg} / \mathrm{cm}^{2}\right)^{7,8,9,10,11,12,13}$ Regarding the safety issue, the average discharge potential of $\sim 0.3 \mathrm{~V} v s . \mathrm{K}^{+} / \mathrm{K}$ makes graphite even more attractive for the application.

In fact, the major drawback of K-ion batteries is the need of positive electrode materials with open structural frameworks to accommodate the large ionic radius of $\mathrm{K}^{+}(1.38 \AA)$ compared to $\mathrm{Na}^{+}(1.02 \AA)$ and $\mathrm{Li}^{+}(0.76 \AA),{ }^{1,14}$ which is detrimental to the volumetric energy density. ${ }^{15}$ Polyanionic compounds are of great interest as they are suitable host 
structures for the reversible $\mathrm{K}^{+}$intercalation as well as to deliver high voltage. ${ }^{16}$ For instance, $\mathrm{KVPO}_{4} \mathrm{~F}(\mathrm{KVPF})$ showed reversible capacity up to $\sim 105 \mathrm{mAh}^{-1} \mathrm{~g}^{-1}$ with an average discharge potential of $\sim 4.3 \quad \mathrm{~V}$ vs. $\mathrm{K}^{+} / \mathrm{K}$ and excellent rate performance. ${ }^{17,18,19,20,21,22}$ In a full-cell configuration using graphite, the energy density has even been evaluated at $300 \mathrm{Wh} \cdot \mathrm{kg}^{-1}$, suggesting a promising material for further fullcell studies. ${ }^{23}$ Regarding its electrochemical behaviour as a positive electrode material, KVPF shows 4 distinct potential domains in both charge and discharge, corresponding to successive phase transitions with an interesting limited lattice volume change of $\sim 6.5$ $\%,{ }^{19}$ and the formation of intermediate phases $\mathrm{K}_{\mathrm{x}} \mathrm{VPO}_{4} \mathrm{~F}$ at $\mathrm{x}=0.75, \mathrm{x}=0.625$ and $\mathrm{x}=0.5$. The reaction occurring at high voltage, between the composition $\mathrm{K}_{0.5} \mathrm{VPO}_{4} \mathrm{~F}$ and $\mathrm{VPO}_{4} \mathrm{~F}$ still remains unclear, however, with simultaneous active material redox reaction and large electrolyte degradation. It may explain why the theoretical capacity of KVPF (131 mAh. $\mathrm{g}^{-1}$ ) was never reached so far. Therefore, it is of great interest to better understand the electrochemical processes involved in KVPF positive electrode materials in KIBs in order to improve its performance.

The present work proposes to investigate the electrochemical redox processes involved in KVPF upon cycling in $\mathrm{K}$ metal batteries using $\mathrm{X}$-ray photoelectron spectroscopy (XPS). The impact of a carbon-coating on the electrochemical performance of KVPF was first evaluated, regarding its ability to improve the overall performance and mitigate the electrolyte degradation.

\section{Experimental}

$\mathrm{KVPO}_{4} \mathrm{~F}$ and carbon coated $\mathrm{KVPO}_{4} \mathrm{~F}\left(\mathrm{KVPO}_{4} \mathrm{~F}-\mathrm{C}\right)$ were prepared by a two-step reaction. First, $\mathrm{VPO}_{4}$ was obtained by mixing $\mathrm{V}_{2} \mathrm{O}_{5}$ (from Sigma-Aldrich, 99.6\%) and $\mathrm{NH}_{4} \mathrm{H}_{2} \mathrm{PO}_{4}$ (from Sigma-Aldrich, 99.99\%) by high energy ball-milling (SPEX 8000M mixer/mill at $1425 \mathrm{rpm}$ ) for $1 \mathrm{hr}$ followed by a thermal treatment at $800^{\circ} \mathrm{C}$ for $7 \mathrm{~h}$ under 
$\mathrm{Ar} / \mathrm{H}_{2}(5 \%)$. Second, stoichiometric amounts of $\mathrm{KF} .2 \mathrm{H}_{2} \mathrm{O}$ (from Alfa Aesar, $98.5 \%$, dried overnight under vacuum at $250^{\circ} \mathrm{C}$ and stored in a glovebox under Ar) and $\mathrm{VPO}_{4}$ were mixed without (KVPF) or with (KVPF-C) the addition of $10 \mathrm{wt} . \%$ sucrose (from Sigma-Aldrich, ACS reagent). The mixture was obtained by SPEX ball-milling for $1 \mathrm{hr}$, pelletized and thermal treated at $650^{\circ} \mathrm{C}$ for $8 \mathrm{~h}$ under Ar. Rietveld refinement of the Xray diffraction patterns was performed using the FullProf software and considering an orthorhombic unit cell described in the Pna $2_{1}$ space group. ${ }^{24}$ It confirmed the nature of the grey (KVPF) and black (KVPF-C) powders obtained (Fig. S1). The smaller cell parameters and especially volume cell obtained for $\mathrm{KVPO}_{4} \mathrm{~F}-\mathrm{C}$ versus the $\mathrm{KVPO}_{4} \mathrm{~F}$ phase reported and characterized in-depth by Fedotov et al. ${ }^{17}$ suggest a partial $\mathrm{O}^{2-}$ substitution for $\mathrm{F}^{-}$and thus the formation of $\mathrm{KVPO}_{4} \mathrm{~F}_{1-\mathrm{y}} \mathrm{O}_{\mathrm{y}} \mathrm{y}$ was estimated to 0.1 from the study of the solid solution $\mathrm{KVPO}_{4} \mathrm{~F}-\mathrm{KVPO}_{4} \mathrm{O}$ (Table S1, and from ${ }^{31} \mathrm{P}$ MAS NMR data not reported here). Note that the stoichiometry in $\mathrm{K} / \mathrm{V} / \mathrm{P}$ was determined by chemical analyses (Fig. S1). In addition, thermogravimetric analyses and scanning electron microscopy images confirmed the formation of a carbon coating $(2.5 \mathrm{wt} . \%$ of C) for KVPF-C compared to KVPF (Fig. S2). Electrodes were prepared by mixing KVPF or KVPF-C, carbon black (Super P, BET $=62 \mathrm{~m}^{2} / \mathrm{g}$, Alfa Aesar) and poly(vinylidene fluoride) according to a 70:25:5 weight ratio, in N-methyl-2-pyrrolidone (32:68 solvent:material weight ratio), by ball-milling for $1 \mathrm{~h}$. The obtained slurry was cast on an aluminium current collector, dried for $24 \mathrm{~h}$ under Ar, and finally electrodes of $1.5 \mathrm{mg}_{\mathrm{KVPO}_{4} \mathrm{~F}} / \mathrm{cm}^{2}$ were punch out and dried under vacuum at $80^{\circ} \mathrm{C}$ for $12 \mathrm{~h} .2032$ cointype cells (316L stainless steel) were assembled under Ar using a Whatman (grade GF/D) and a polypropylene membrane (Celgard) as separators, K metal (99.95\%, Alfa Aesar) as negative electrode and $100 \mu \mathrm{L}$ of $0.8 \mathrm{M} \mathrm{KPF}_{6}$ in a mixture of EC:DEC by volume as electrolyte $\left(\mathrm{KPF}_{6}\right.$, Sigma-Aldrich, $\geqslant 99 \%$; EC, Sigma-Aldrich, anhydrous, 
$99 \%$; DEC, Sigma-Aldrich, anhydrous, $\geqslant 99 \%$ ). All potentials reported in the text are referred to $\mathrm{K}^{+} / \mathrm{K}$. Note that $\mathrm{K}$ metal polarization in symmetrical $\mathrm{K} / \mathrm{K}$ cell was found negligible during open circuit voltage $\left(<6 \mathrm{mV}\right.$, Fig. S3) compared to the literature. ${ }^{25}$ During plating/stripping at $0.04 \mathrm{~mA} / \mathrm{cm}^{2}$ (corresponding to the current used to cycle $\mathrm{K} / / \mathrm{KVPF}$ cells), however, a polarization of $0.1 \mathrm{~V}$ was measured. Cycling tests were performed at $\mathrm{C} / 5\left(26 \mathrm{~mA} \cdot \mathrm{g}^{-1}\right.$, i.e. the exchange of $1 \mathrm{~K}^{+}$in 5 hours $)$ and $20^{\circ} \mathrm{C}$ using a VMP3 (Biologic, SAS France). Two formation cycles were first performed between 3.5$5 \mathrm{~V}$ vs. $\mathrm{K}^{+} / \mathrm{K}$ to minimize electrolyte degradation impact (Fig. $\mathbf{S 4}$ and Fig. 3), as discussed later. KVPF-C cells were then stopped at different potentials during the $3^{\text {rd }}$ cycle and electrodes were recovered from the cells and washed twice with $1 \mathrm{~mL}$ of DEC during 30s. XPS analysis was performed using an Escalab 250 Xi spectrometer, with a monochromatized Al K $\alpha$ radiation $(\mathrm{h} v=1486.6 \mathrm{eV})$. Electrodes were placed on a sample holder using uPVC insulation tape (3M part number 655), and transferred to Ar filled glove box connected to the spectrometer. Using the standard charge compensation mode, core spectra were recorded with a $0.15 \mathrm{eV}$ step and a constant $20 \mathrm{eV}$ pass energy. Using CasaXPS software, the binding energy scale was calibrated from the KVPF oxygen peak at $530.0 \mathrm{eV}$. It is reminded that XPS probes about 5 to $10 \mathrm{~nm}$ depth of the sample surface, and here between 6-7 $\mathrm{nm}$ for the vanadium, i.e. not only the extreme surface atomic layers $(0.5-1 \mathrm{~nm})$ but also the deeper ones, which means a representative part of the bulk is also probed (Fig. S5). Moreover, at the extreme surface, the presence of defects may lead to vanadium with an oxidation state higher or lower than in the bulk. V $2 \mathrm{p}_{3 / 2}$ core spectra of KVPF electrodes were thus fitted using peak positions and line shapes constraints corresponding to different oxidation states as determined from reference samples with $\mathrm{V}^{\mathrm{n}+}$ in a $\mathrm{PO}_{4}$ environment (Fig. S5 and Table S2) in agreement with the literature. ${ }^{26,27,28,29,30}$ This thorough procedure allows reliably following the evolution of 
the mean oxidation state upon cycling, especially considering that the mean oxidation state obtained by XPS (3.1) for the pristine KVPF-C material is in good agreement with the $\mathrm{XRD}$ analysis $\left(\mathrm{KVPO}_{4} \mathrm{~F}_{1-\mathrm{y}} \mathrm{O}_{\mathrm{y}}\right.$ with $\left.\mathrm{y}=0.1\right)$.

\section{Results and discussion}

The impact of the carbon coating was evaluated regarding its ability to optimize the electrochemical performance of the material in KIBs and to mitigate the KVPF active material surface reactivity against the electrolyte. Overall, both KVPF and KVPF-C showed a similar charge/discharge profile at C/5 with 4 potential domains (Fig. S4), in very good agreement with the literature. ${ }^{19}$ However KVPF-C showed a lower average polarization of $\sim 230 \mathrm{mV}$ compared to $\sim 300 \mathrm{mV}$ for KVPF (Fig. S4) and a better capacity retention after 70 cycles compared to KVPF (76 \% vs $62 \%$, (Fig. S6). For both systems, a significant high-potential hysteresis is observed, suggesting that the main capacity loss would be related to the high-potential domain. Since KVPF and KVPF-C have close particles size (Fig. S2), the carbon coating was shown - as expected - to promote better transport properties within the positive electrode, lower polarization of the cell, smaller electrolyte degradation at high voltage and thus optimized performances. XPS analysis confirmed a significantly lower solid electrolyte interphase coverage at the KVPF-C surface compared to KVFP after the first cycle (Table S3). Note that the lower electrolyte degradation is explained by a passivation effect of the carbon coating at the KVPF surface. Based on these results, KVPF-C was therefore selected to study the electrochemical redox processes involved in $\mathrm{KVPO}_{4} \mathrm{~F}$ upon cycling.

Fig. 1a shows the typical $3^{\text {rd }}$ charge/discharge cycle obtained for K/KVPF-C cells and indicates at which potentials the prepared cells were stopped to perform the analysis of 
the redox processes involved in KVPF-C. Note that charge/discharge profiles obtained for all the cells showed very close polarization and capacities (Fig. S7), highlighting the great reproducibility of the electrochemical results so that reliable XPS analysis is expected on materials recovered ex situ from this series of cells. Fig. 1b shows the V $2 \mathrm{p}_{3 / 2} \mathrm{XPS}$ core spectra of $\mathrm{K}_{\mathrm{x}} \mathrm{V}^{\mathrm{n}+} \mathrm{PO}_{4} \mathrm{~F}-\mathrm{C}$ electrodes as recovered from $\mathrm{K} / \mathrm{KVPF}-\mathrm{C}$ cells during the third cycle at $\mathrm{C} / 5$, as function of the $\mathrm{K}$ content. For more information, the full V 2p core spectra can be found in Fig. S8. XPS analysis revealed that the pristine KVPF$\mathrm{C}$ showed the presence of $\mathrm{V}^{2+}, \mathrm{V}^{3+}$ and $\mathrm{V}^{4+}\left(\right.$ Fig. 1b) although only $\mathrm{V}^{3+}$ and $\mathrm{V}^{4+}$ were expected based on the $\mathrm{KVPO}_{4} \mathrm{~F}_{0.9} \mathrm{O}_{0.1}-\mathrm{C}$ formula. Note that $\mathrm{V}^{2+}$ was also observed for the $\mathrm{VPO}_{4}$ precursor (Fig. S5). However, considering the very low amount $(<1 \mathrm{wt} . \%)$ of $\mathrm{VPO}_{4}$ impurity in the KVPF-C material (Fig. S1), the presence of $\mathrm{V}^{2+}$ is likely to originate from the KVPF-C extreme surface. This was supported by the decrease of the $\mathrm{V}^{2+}$ contribution during oxidation as discussed thereafter.

After charge of the cell to $4.10 \mathrm{~V}$, i.e. during the $1^{\text {st }}$ oxidative potential domain, the peak associated with $\mathrm{V}^{4+}$ increased while the $\mathrm{V}^{3+}$ and $\mathrm{V}^{2+}$ ones decreased (respectively $+7 \%$, $-4 \%$ and $-3 \%$ ). At almost the end of the $2^{\text {nd }}$ potential domain at $4.30 \mathrm{~V}$ (i.e. at the composition of about $\mathrm{K}_{0.625} \mathrm{VPO}_{4} \mathrm{~F}$ ), the peak associated with $\mathrm{V}^{4+}$ increased while the peaks associated with $\mathrm{V}^{3+}$ and $\mathrm{V}^{2+}$ decreased (respectively $+15 \%,-12 \%$ and $-3 \%$ ). At the end of the $3^{\text {rd }}$ potential domain at $4.46 \mathrm{~V}$ (i.e. for approx. $\mathrm{K}_{0.5} \mathrm{VPO}_{4} \mathrm{~F}$ ), a new peak, attributed to $\mathrm{V}^{5+}$ appeared $(+13 \%)$ while the $\mathrm{V}^{4+}, \mathrm{V}^{3+}$ and $\mathrm{V}^{2+}$ peaks decreased $(-11 \%$, $1 \%$ and $-1 \%$, respectively). This phenomenon further continued after the $4^{\text {th }}$ potential domain at $5.00 \mathrm{~V}$, so that the $\mathrm{V}^{5+}, \mathrm{V}^{4+}, \mathrm{V}^{3+}$ and $\mathrm{V}^{2+}$ peaks represent $20 \%, 50 \%, 23 \%$ and $7 \%$, respectively. Note that despite the remaining $\mathrm{V}^{3+}$ and $\mathrm{V}^{2+}$ even at the end of charge, the corresponding mean oxidation states were in good agreement with the theoretical/electrochemical ones, as discussed thereafter. Note that remaining of $\mathrm{V}^{3+}$ and 
$\mathrm{V}^{2+}$ at the end of charge should arise from specific vanadium environment at the KVPF surface. During discharge, opposite phenomena were observed (Fig. 1b), indicating a high reversibility of the redox processes involved in KVPF-C upon cycling in the potential window $3.5-5 \mathrm{~V} v s . \mathrm{K}^{+} / \mathrm{K}$.

The evolution of the vanadium mean oxidation state as the $\mathrm{K}$ content changed during the $3^{\text {rd }}$ cycle for $\mathrm{KVPO}_{4} \mathrm{~F}_{0.9}-\mathrm{O}_{0.1} \mathrm{C}$ and determined from both the charge/discharge capacity $\left(\mathrm{DO}_{\text {elec }}\right)$ and XPS analysis $\left(\mathrm{DO}_{\mathrm{xps}}\right)$ is reported in Fig. 2.

Until the end of the $3^{\text {rd }}$ potential domain, i.e. at $4.46 \mathrm{~V}$, a very good agreement was observed between the vanadium mean oxidation states determined from the electrochemistry and from XPS analysis. On the contrary, at the end of the $4^{\text {th }}$ potential domain, i.e. at $5.00 \mathrm{~V}, \mathrm{DO}_{\text {elec }}$ was +3.9 while $\mathrm{DO}_{\mathrm{xps}}$ was only +3.8 . This discrepancy indicates that about $25 \%$ of the electrons exchanged in the last potential domain are not related to $\mathrm{K}^{+}$deintercalation from $\mathrm{KVPF}-\mathrm{C}$ but to electrolyte degradation. This is in agreement with the high irreversible capacity observed for the $4^{\text {th }}$ potential domain between the charge and the next discharge (Fig. 1a). Moreover, the evolution of the capacities associated with the different potential domains for the first 20 cycles showed that electrolyte degradation is mainly associated with the $4^{\text {th }}$ potential domain as shown in Fig. 3 by the large difference in height between the full and hatched black bars. Nevertheless, during the first two cycles, irreversibility was observed throughout the reaction, the latter being much more pronounced at high voltage (about 60\%, Fig. 3). During the next cycles, a stabilization was observed with an excellent efficiency below 4.6 V (same height for the full and hatched blue and green bars), and thus a capacity loss almost exclusively associated with the high voltage domain (about 90\%) and the composition range $\mathrm{K}_{0.5} \mathrm{VPO}_{4} \mathrm{~F}-\mathrm{C}-\mathrm{VPO}_{4} \mathrm{~F}-\mathrm{C}$. This highlights the relevance of using the 
$3^{\text {rd }}$ cycle to perform the redox processes study instead of the $1^{\text {st }}$ cycle. During discharge, $\mathrm{DO}_{\text {xps }}$ decreased back to +3.1 (Fig. 2), indicating a complete reversibility of the redox processes. This result fully supports the limitation of the participation of the electrolyte degradation to high voltage, only after the $2^{\text {nd }}$ cycle as shown in Fig. 3.

Importantly, only $0.7 \mathrm{~K}^{+}$were extracted from $\mathrm{KVPO}_{4} \mathrm{~F}_{0.9}-\mathrm{O}_{0.1}-\mathrm{C}$ (Fig. 2) instead of 0.9 theoretically. Especially, the capacity associated with the $1^{\text {st }}, 2^{\text {nd }}$ and $3^{\text {rd }}$ potential domains nearly reached the theoretical ones and remained almost constant from cycles 3 to 20 (Fig. 3). On the contrary, the $4^{\text {th }}$ potential domain capacity continuously decreased to about half the theoretical one from cycle 3 to 20 (Fig. 3). Interestingly, no polarization increase (due to the accumulation of electrolyte degradation products) was observed (Fig. S9). Thus, the $4^{\text {th }}$ potential domain capacity decrease is not explained by the cut-off potential being reached before the end of the domain. Instead, these results likely originate from structural constraints hindering the extraction (and insertion) of $\mathrm{K}^{+}$ from $\mathrm{x}=0.5$ to $\mathrm{x}=0$ as proposed previously. ${ }^{19,31}$ To evaluate the possibility to further extract the remaining $\mathrm{K}^{+}$, a cell was hold at $5 \mathrm{~V}$ for $18 \mathrm{~h}$ during the $3^{\text {rd }}$ cycle and the corresponding $\mathrm{DO}_{\mathrm{xps}}$ was +3.9 (Fig. S10), in agreement with the evolution of the cell parameters determined by XRD (not shown). This result highlights that despite the electrolyte degradation process, it is still possible to extract the potassium but the process is much slower, more likely due to a structural constraint such as cell volume reduction. This structural constraint could increase the $\mathrm{K}^{+}$migration barrier, inducing a decrease in the $\mathrm{K}^{+}$diffusion coefficient, ${ }^{31}$ slowing the global extraction process.

\section{Conclusion}

In conclusion, the carbon coating of the KVPF material was found beneficial to the overall electrochemical performance while mitigating electrolyte degradation at high 
voltage. Then, by comparing the average oxidation state derived from electrochemical and XPS analysis, the electrochemical redox processes of $\mathrm{K}_{\mathrm{x}} \mathrm{VPO}_{4.1} \mathrm{~F}_{0.9}-\mathrm{C}$ were revealed. Interestingly, a high reversibility was found although the $\mathrm{K}^{+}$extraction (and insertion) from $x=0.5$ to $x=0$ was hindered, possibly by structural constraints. Moreover, the severe electrolyte degradation issue, observed mostly above $4.5 \mathrm{~V}$, is currently under further investigation, as well as possible KVPF dissolution in order to successfully mitigate these irreversible degradation reactions using electrolyte additives and enable highly efficient KVPF based full K-ion cells.

\section{Conflicts of interest}

There are no conflicts of interest to declare.

\section{Acknowledgments}

The authors thank the financial support of E2S-UPPA, Région Nouvelle Aquitaine and the French National Research Agency (STORE-EX Labex Project ANR-10-LABX-76-01 and TROPIC project ANR-19-CE05-0026-01). The authors thank Cathy DENAGE, Etienne DURAND and Eric LEBRAUD (ICMCB) for their help with SEM, TGA-FTIR and XRD analyses, respectively. Authors also thank Joël GAUBICHER (IMN-Nantes) for fruitful discussions about redox processes in KVPF.

\section{References}

1. K. Kubota, M. Dahbi, T. Hosaka, S. Kumakura, and S. Komaba, Chem. Rec., 18, 1-22 (2018).

2. T. A. Pham, K. E. Kweon, A. Samanta, V. Lordi, and J. E. Pask, J. Phys. Chem. C, 121, 21913-21920 (2017).

3. L. Madec, V. Gabaudan, G. Gachot, L. Stievano, L. Monconduit, and H. Martinez, ACS Appl. Mater. Interfaces, 10, 34116-34122 (2018).

4. V. Gabaudan, L. Monconduit, L. Stievano, and R. Berthelot, Front. Energy Res., 7 (2019). 
5. Z. Jian, W. Luo, and X. Ji, J. Am. Chem. Soc., 137, 11566-11569 (2015).

6. J. C. Pramudita, V. K. Peterson, J. A. Kimpton, and N. Sharma, Powder Diffr., 32, S43S48 (2017).

7. L. Fan, R. Ma, Q. Zhang, X. Jia, and B. Lu, Angew. Chemie - Int. Ed., 58, 10500-10505 (2019).

8. S. Komaba, T. Hasegawa, M. Dahbi, and K. Kubota, Electrochem. commun., 60, 172-175 (2015) http://dx.doi.org/10.1016/j.elecom.2015.09.002.

9. W. Luo, J. Wan, B. Ozdemir, W. Bao, Y. Chen, J. Dai, H. Lin, Y. Xu, F. Gu, V. Barone, and L. Hu, Nano Lett., 15, 7671-7677 (2015).

10. Y. An, H. Fei, G. Zeng, L. Ci, B. Xi, S. Xiong, and J. Feng, J. Power Sources, 378, 66-72 (2018) https://doi.org/10.1016/j.jpowsour.2017.12.033.

11. X. Niu, L. Li, J. Qiu, J. Yang, J. Huang, Z. Wu, J. Zou, C. Jiang, J. Gao, and L. Wang, Solid State Ionics, 341, 2-7 (2019).

12. R. A. Adams, A. Varma, and V. G. Pol, J. Power Sources, 410-411, 124-131 (2019) https://doi.org/10.1016/j.jpowsour.2018.11.007.

13. M. Carboni, A. J. Naylor, M. Valvo, and R. Younesi, RSC Adv., 9, 21070-21074 (2019) http://dx.doi.org/10.1039/C9RA01931F.

14. C. Vaalma, D. Buchholz, and S. Passerini, Curr. Opin. Electrochem., 9, 41-48 (2018).

15. X. Wu, D. P. Leonard, and X. Ji, Chem. Mater., 29, 5031-5042 (2017).

16. T. Hosaka, T. Shimamura, K. Kubota, and S. Komaba, Chem. Rec., 19, 735-745 (2019).

17. S. S. Fedotov, N. R. Khasanova, A. S. Samarin, O. A. Drozhzhin, D. Batuk, O. M.

Karakulina, J. Hadermann, A. M. Abakumov, and E. V. Antipov, Chem. Mater., 28, 411-415 (2016).

18. K. Chihara, A. Katogi, K. Kubota, and S. Komaba, Chem. Commun., 53, 5208-5211 (2017).

19. H. Kim, D. H. Seo, M. Bianchini, R. J. Clément, H. Kim, J. C. Kim, Y. Tian, T. Shi, W. S. Yoon, and G. Ceder, Adv. Energy Mater., 8, 1-12 (2018).

20. H. Kim, Y. Ishado, Y. Tian, and G. Ceder, Adv. Funct. Mater., 29, 1-8 (2019).

21. J. Liao, Q. Hu, X. He, J. Mu, J. Wang, and C. Chen, J. Power Sources, 451, 1-8 (2020).

22. Z. Liu, J. Wang, and B. Lu, Sci. Bull. (2020) https://doi.org/10.1016/j.scib.2020.04.010.

23. T. Hosaka, K. Kubota, A. S. Hameed, and S. Komaba, Chem. Rev. (2020).

24. Juan Rodriguez-Carvajal, Phys. B, 192, 55-69 (1993).

25. T. Hosaka, S. Muratsubaki, K. Kubota, H. Onuma, and S. Komaba, J. Phys. Chem. Lett. 10, 3296-3300 (2019).

26. G. Silversmit, D. Depla, H. Poelman, G. B. Marin, and R. De Gryse, J. Electron Spectros. Relat. Phenomena, 135, 167-175 (2004).

27. A. Benayad, H. Martinez, A. Gies, B. Pecquenard, A. Levasseur, and D. Gonbeau, J. 
Electron Spectros. Relat. Phenomena, 150, 1-10 (2006).

28. A. Benayad, H. Martinez, A. Gies, B. Pecquenard, A. Levasseur, and D. Gonbeau, J. Phys. Chem. Solids, 67, 1320-1324 (2006).

29. B. Fleutot, H. Martinez, B. Pecquenard, J. B. Ledeuil, A. Levasseur, and D. Gonbeau, J. Power Sources, 180, 836-844 (2008).

30. E. Hryha, E. Rutqvist, and L. Nyborg, Surf. Interface Anal., 44, 1022-1025 (2012).

31. S. S. Fedotov, N. D. Luchinin, D. A. Aksyonov, A. V. Morozov, S. V. Ryazantsev, M. Gaboardi, J. R. Plaisier, K. J. Stevenson, A. M. Abakumov, and E. V. Antipov, Nat. Commun., 11, 1484 (2020) http://www.nature.com/articles/s41467-020-15244-6. 

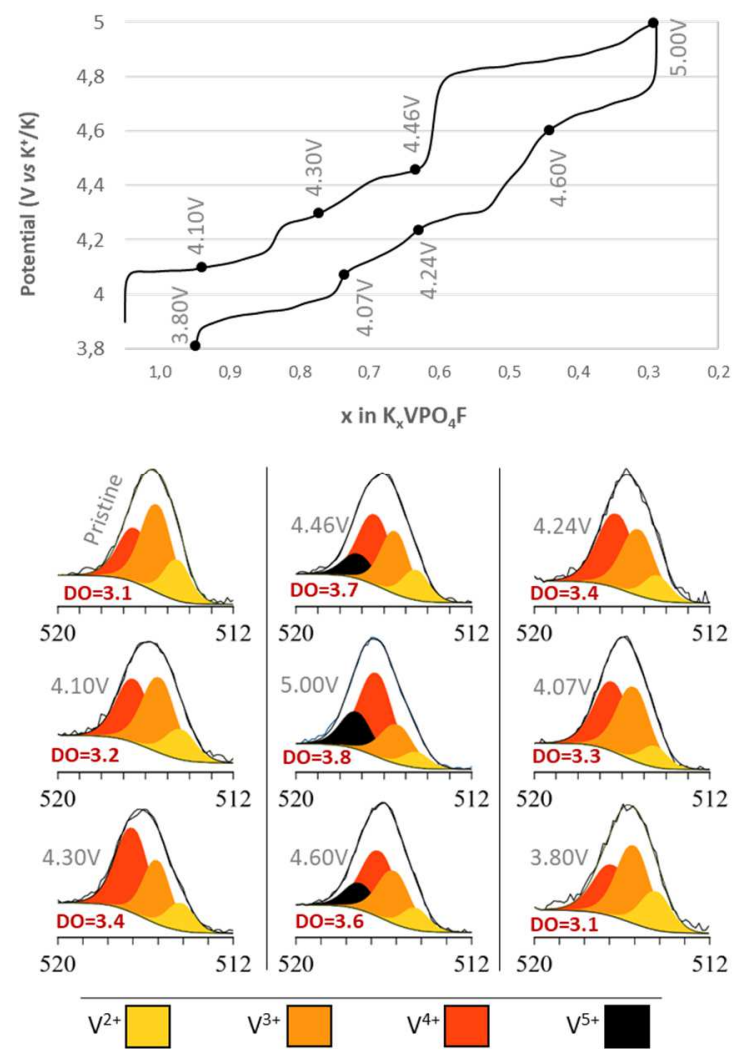

Fig. 1 a) Typical $3^{\text {rd }}$ charge/discharge cycle (at C/5, 26 mA.g ${ }^{-1}$ ) obtained for K//KVPFC cells indicating at which potentials cells were stopped for the analysis of the redox processes involved in KVPF-C. b) Vanadium 2 $\mathrm{p}_{3 / 2}$ XPS core spectra of $\mathrm{K}_{\mathrm{x}} \mathrm{V}^{\mathrm{n}+} \mathrm{PO}_{4} \mathrm{~F}_{0.9} \mathrm{O}_{0.1}-\mathrm{C}$ electrodes as recovered from $\mathrm{K} / / \mathrm{KVPF}-\mathrm{C}$ cells during the $3^{\text {rd }}$ cycle, as function of the potential. 


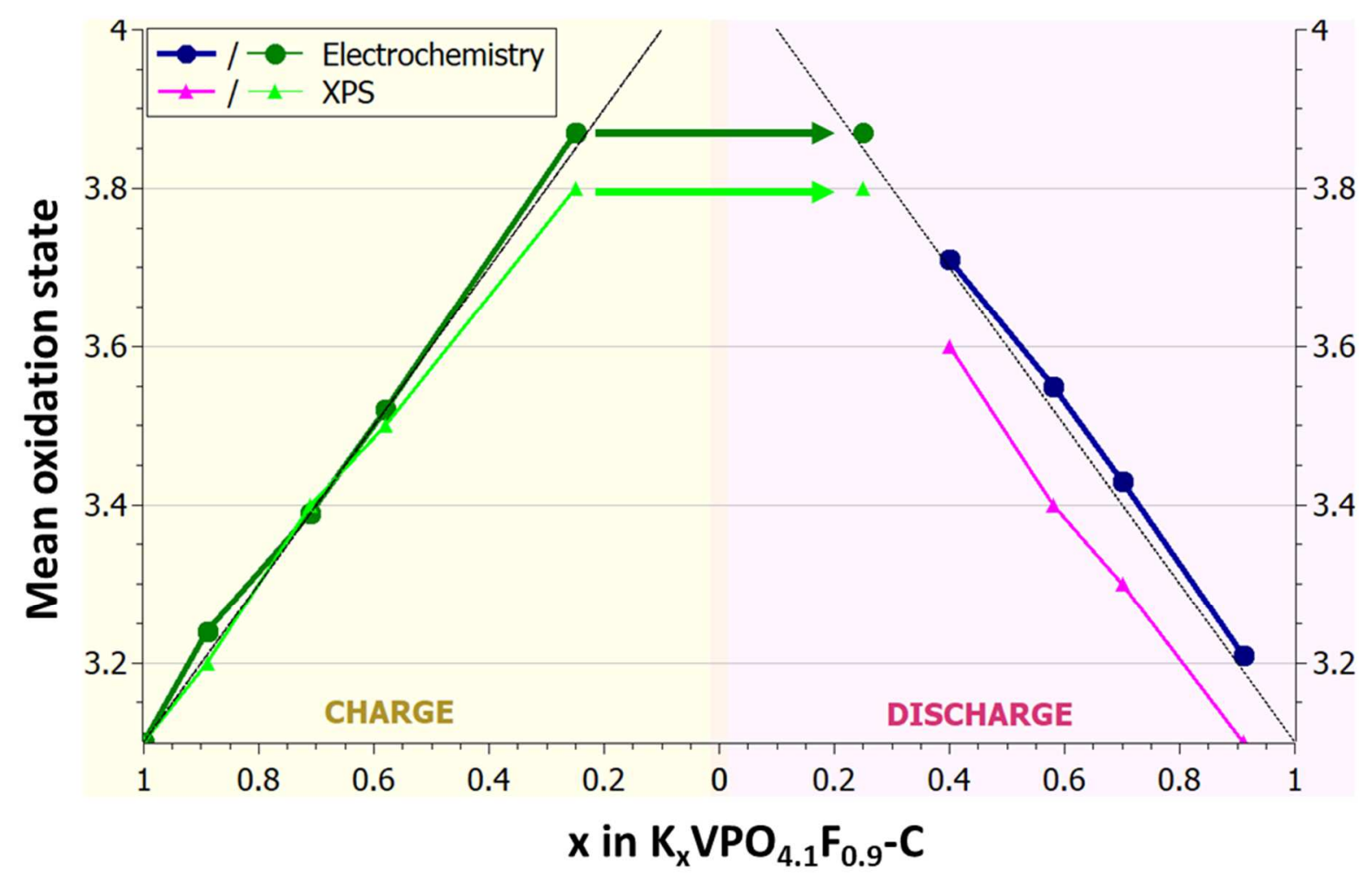

Fig. 2. Vanadium mean oxidation state (DO) of $\mathrm{KVPO}_{4} \mathrm{~F}_{0.9}-\mathrm{O}_{0.1}-\mathrm{C}$, as the $\mathrm{K}$ content changed during the $3^{\text {rd }}$ cycle, determined from the charge/discharge capacity on one side and from the analysis of the XPS spectra on the other side. Grey lines represent the theoretical DO based on the $\mathrm{KVPO}_{4} \mathrm{~F}_{0.9}-\mathrm{O}_{0.1}-\mathrm{C}$ formula. 


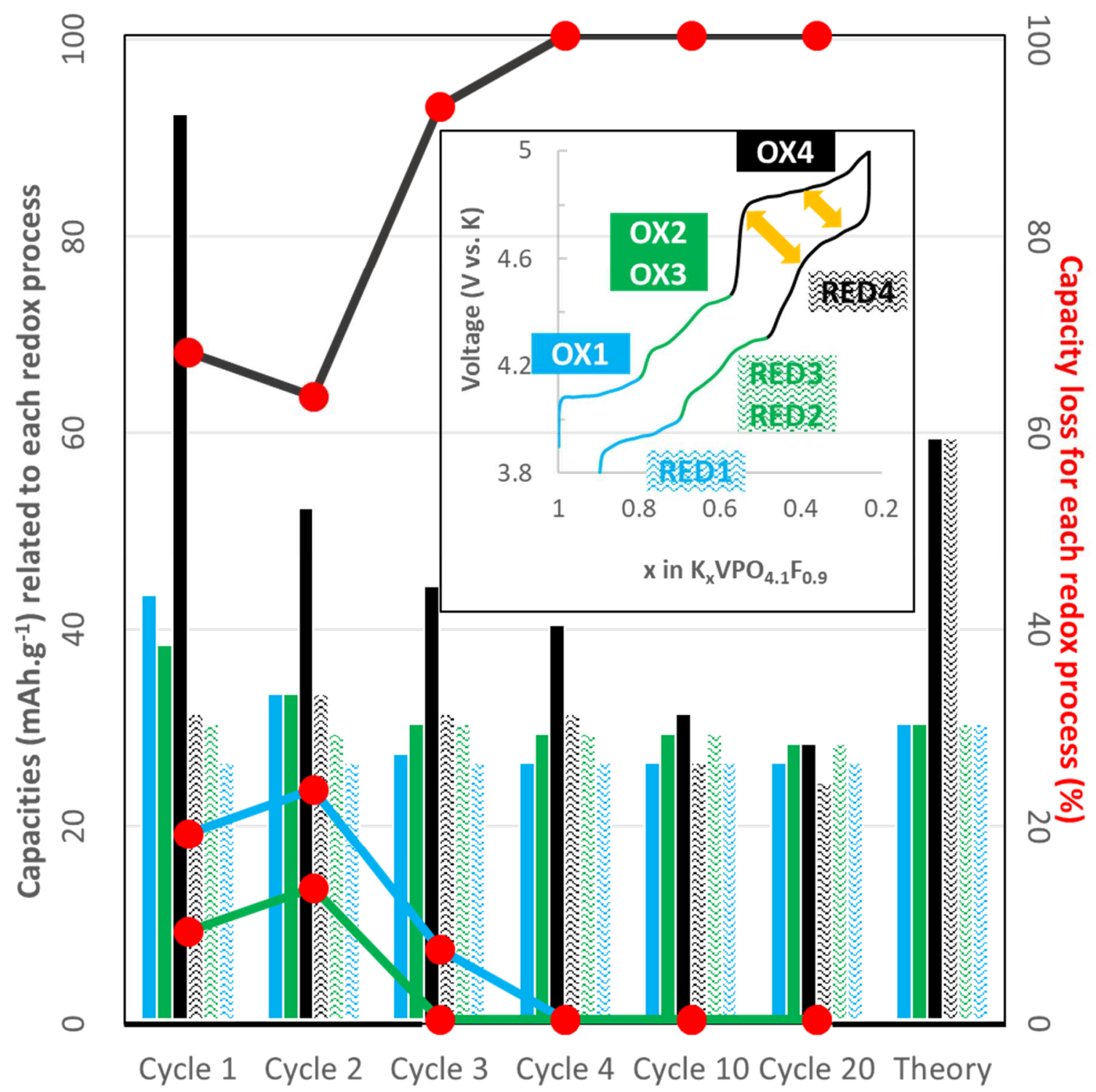

Fig. 3 Capacity (mAh. $\mathrm{g}^{-1}$ ) related to the $1^{\text {st }}, 2^{\text {nd }}, 3^{\text {rd }}$ and $4^{\text {th }}$ redox processes as obtained from the derivative of the galvanostatic charge/discharge curves. Note that the $2^{\text {nd }}$ and $3^{\text {rd }}$ potential domainss were combined as they cannot be perfectly dissociated after few cycles (not shown). Corresponding capacity loss $(\%)$ between oxidation and reduction is also reported by the curves with the red points. Theoretical capacity of the different redox processes based on the $\mathrm{KVPO}_{4} \mathrm{~F}_{0.9}-\mathrm{O}_{0.1} \mathrm{C}$ formula $\left(118 \mathrm{mAh.g}{ }^{-1}\right)$ are also reported for comparison. 